\title{
Severe Acute Respiratory Syndrome-Related Coronavirus: A Patent Based View
}

\author{
Mayuree Sengupta, H. Purushotham* \\ National Research Development Corporation, 20-22 Zamroodpur Community Centre, Kailash Colony Extn., \\ New Delhi 110048, India
}

*Corresponding author: E-mail: cmdnrdc@nrdc.in; Tel.: (+91) 11-29241212

DOI: $10.5185 /$ amlett.2020.051503

Severe Acute Respiratory Syndrome-Related Coronavirus 2(SARS-CoV2) or the COVID-19 virus has led to a global pandemic causing havoc all across. While researching methods to contain the virus or a cure is still a work-in-progress, a feasible way would be to delve into the patent landscape of SARS-CoV to locate pertinent innovations on the block. The similarity in viral proteins of SARS-CoV and SARS-CoV2 enables the credence that patent applications and granted patents on SARS-CoV may offer beneficial insights towards understanding and finding a solution to COVID-19 disease.

\section{Introduction}

Severe Acute Respiratory Syndrome Coronaviruses (SARS-CoV) is a zoonotic virus in all likelihood originating from Chinese horseshoe bats, amplified in palm civets and raccoon dogs in the live animal markets, and subsequently transmitted into unsuspecting human populations [1]. In late November-December, 2019 patients suffering from viral pneumonia on account of an unidentified microbial agent were reported in Wuhan, China. A novel coronavirus was subsequently identified as the causative pathogen [2]. The Coronaviridae Study Group (CSG) of the International Committee on Taxonomy of Viruses (ICTV) has recognized this coronavirus-associated acute respiratory disease called coronavirus disease 19 (COVID-19) virus as forming a sister clade to the prototype human and bat severe acute respiratory syndrome coronaviruses (SARS-CoVs of the species Severe acute respiratory syndrome-related coronavirus, and designated it as SARS-CoV-2 [3]. The spread of SARS-CoV-2 has already taken on pandemic proportions, affecting over 100 countries in weeks [4]. The COVID-19 has spread to 210 countries and the death toll stands at a perilous 165, 741 till date [5]. Epidemiological parameters supporting pathogen-human interactions are responsible for worldwide infection spread of COVID-19 [6]. Initial infections were zoonotic, however later it spread worldwide more rapidly due to human-human interaction [7].

The world needs to discover an antidote to this virus, and soon, to rein in the morbidity. Research reveals that amongst the two, SARSCoV-2 is more transmissible/ contagious than SARS-CoV [8]. It has also been demonstrated that the viral proteins responsible for entry of SARS-CoV-2 into host cells and subsequent replication are structurally similar to those associated with SARS$\mathrm{CoV}$. Therefore, both patent applications and granted patents on SARS-CoV may offer beneficial insights towards understanding and treating COVID-19 disease
[9]. It is with this goal that we explore the patent $\uparrow[\mathbf{1 0}]$ landscape of SARS-CoV.

\section{Coronavirus traits}

The term "coronavirus" is derived from the Latin corona, meaning crown or halo and refers to the typical visual of virions under electron microscopy with a fringe of large, bulbous surface projections manifesting an image reminiscent of a royal crown or of the solar corona[11]. Coronavirus family comprises large group of enveloped, positive-sense and single stranded RNA viruses [12]. Before 2019, only six CoVs were known to infect human and cause respiratory diseases, namely, $\mathrm{HCoV}-229 \mathrm{E}$, HCoV-OC43, HCoV-NL63, and HKU11 leading to mild upper respiratory disease and SARS-CoV, MERS$\mathrm{CoV}$ causing severe lower respiratory syndromes in humans [13]. While SARS-Cov2 originated from bats, intermediate animal host between bat reservoir and humans has not been identified yet [14]. However, existence of multiple lineages of pangolin CoVs with genetic similarity to 2019-nCoV does exist [15].

\section{Methodology}

The key strings and related terms for "Severe Acute Respiratory Syndrome-Related Coronavirus" was run in Questal Orbit database. The initial search generated a patent set of 8124 results. The search was limited to Title, Abstract, Claims, and Object of Invention fields; one member per patent family of a total 880 families was considered for further analysis. Patent records considered for this study are updated till $13^{\text {th }}$ April 2020.

\section{Results \& discussion}

The patent applicants/patentees for SARS-CoV belong to the following jurisdictions as depicted in Fig. 1. The jurisdictions comprise USA, Canada, China, Hongkong, South Korea, Russia, France, Germany, Italy, UK, Spain, Israel and Japan etc. incidentally, amongst these, China, 


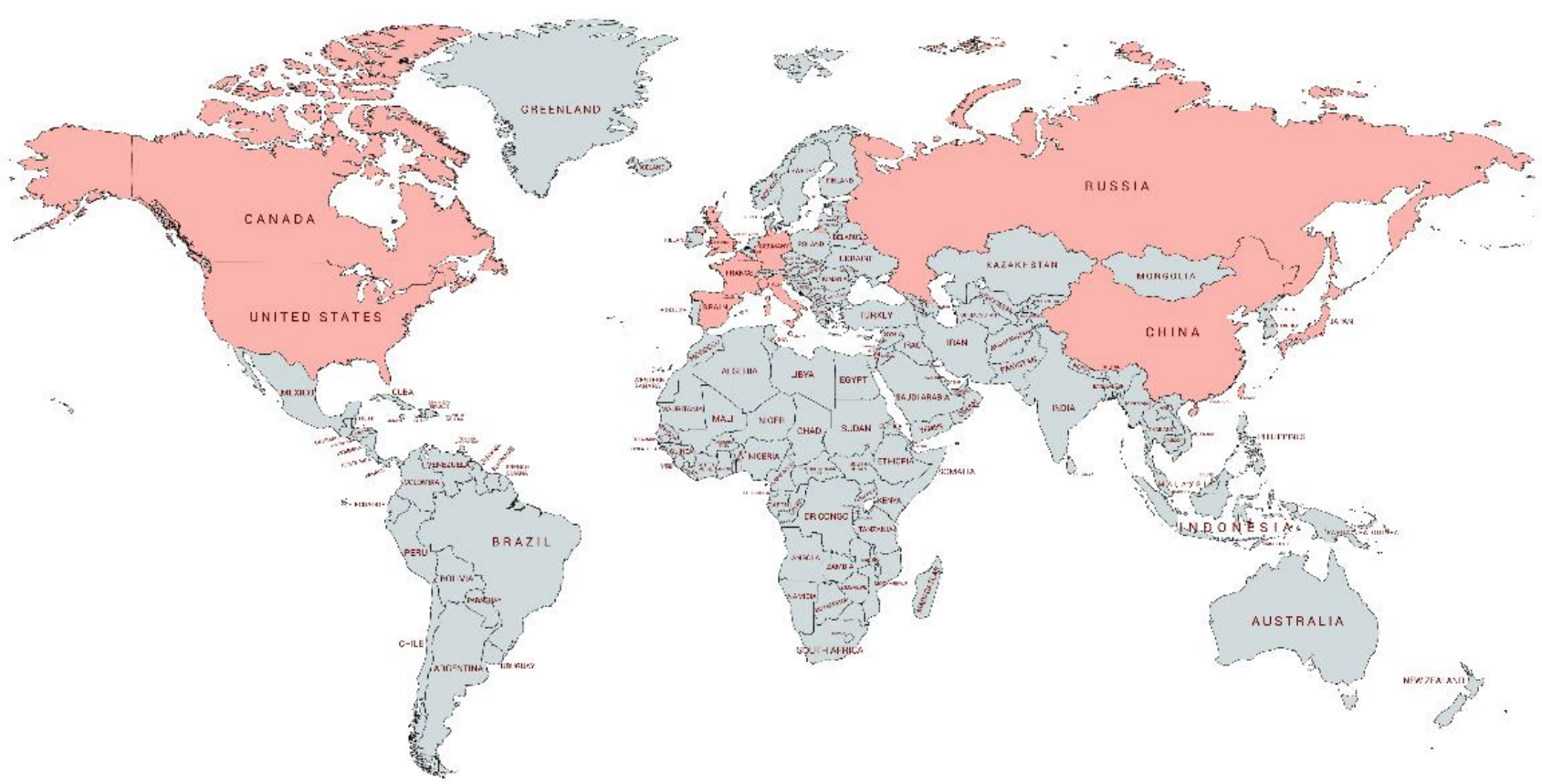

Fig. 1. Jurisdictions of Patent Assignees as per authors' patent study.

Hong Kong, USA, UK, Italy, Spain happen to be the worst affected ones. The leading applicants in terms of patent filing include Novartis, Pfizer, GSK, AstraZeneca, Medimmune, Wyeth, Zortex amongst firms and University of Pennysylvania, University of California INSERM, CNRS amongst academic institutions [16].

An analysis of shortlisted patent/applications revealed the following repetitive key terms in patent specifications as depicted in a word cloud in Fig. 2. We have assessed the patents to broadly fall within three categories for the purposes of detection, treatment and prevention, namely; diagnostic methods, vaccines and pharmaceutical compositions.

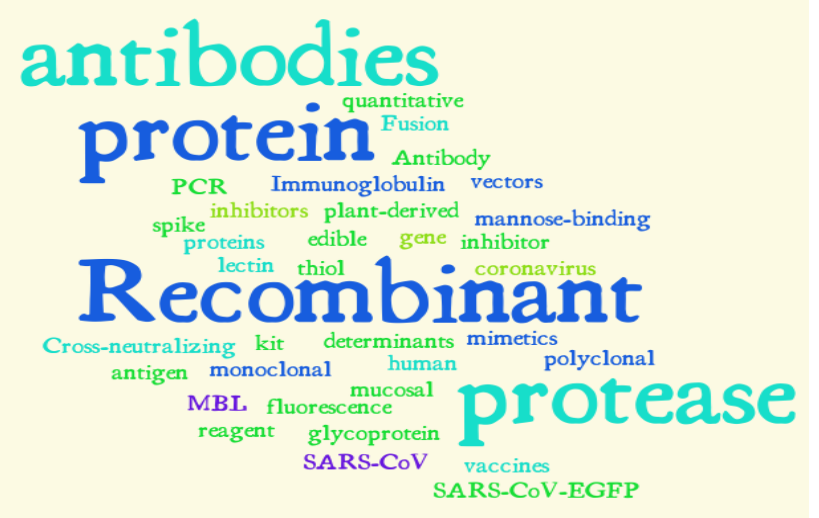

Fig. 2. Visualization of repetitive key terms in patent specifications.

- Patents about SARS-CoV diagnostic methods

SARS-CoV diagnostic methods $\dagger$ [17] predominantly comprise those based on recombinant techniques. A representation of the varied diagnostic methods is reflected in Table 1.
Table 1. Diagnostic tool patent sample for SARS-CoV.

\begin{tabular}{|c|c|c|}
\hline Patent No. & Inventive Concept & Mechanism \\
\hline CN103205509 & $\begin{array}{l}\text { High-flux non-diagnostic } \\
\text { detection }\end{array}$ & $\begin{array}{l}\text { Suspension chip } \\
\text { technology }\end{array}$ \\
\hline EP1639374 & $\begin{array}{l}\text { Based on antigenicity of } \\
\text { S, M, E, N and U } 274 \\
\text { proteins of SARS } \\
\text { coronavirus }\end{array}$ & $\begin{array}{l}\text { Antibody based } \\
\text { detection }\end{array}$ \\
\hline RU2253870 & $\begin{array}{l}\text { Identification of protein } \\
\text { antigen epitope SARS- } \\
\text { CoV }\end{array}$ & $\begin{array}{l}\text { Recombinant } \\
\text { DNA techniques }\end{array}$ \\
\hline KR20080012449 & $\begin{array}{l}\text { Using Nucleocapsid or } \\
\text { Spike Protein of Sars-Cov } \\
\text { Mutated Coronavirus as } \\
\text { an Antigen }\end{array}$ & $\begin{array}{l}\text { Genetic } \\
\text { Engineering } \\
\text { processes }\end{array}$ \\
\hline CN109355365 & $\begin{array}{l}\text { RNA capture and sRNA- } \\
\text { seq,RC\&sRNA small-seq }\end{array}$ & $\begin{array}{l}\text { Small RNA-based } \\
\text { high throughput } \\
\text { sequencing }\end{array}$ \\
\hline
\end{tabular}

- Patents about SARS-CoV vaccines

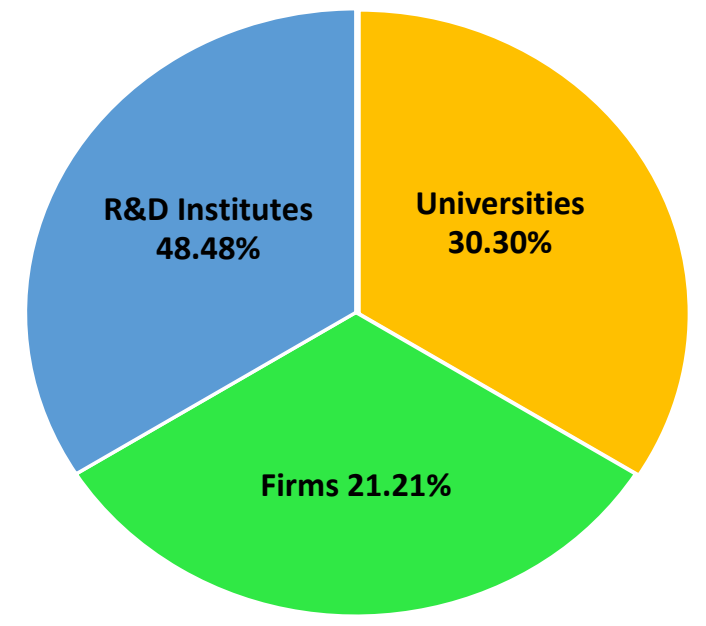

Fig. 3. Assignee Distribution SARS-CoV vaccines. 


\section{Advanced Materials Letters www. vbripress.com/aml}

The assignee distribution of SARS-CoV vaccines is depicted in Fig. 3. Of the total patents (both applications and granted) on SARS-CoV, $10.54 \%$ comprise those on vaccines. Amongst all these patents (both applications and granted), universities $\dagger$ [18] form $30.30 \%$ of the assignee/ inventors. Firms $\dagger$ [19] comprise $21.21 \%$ of the crust. Research organizations $\dagger[20]$ are the principal innovators in this segment at $48.48 \%$. The mechanisms of the vaccines are varied, from attenuated to gene based to those employing nano-delivery system, some representative ones are depicted in Table 2.

Table 2. Types of SARS-CoV Vaccine Patents.

\begin{tabular}{|c|c|}
\hline Patent Nos. (representative sample) & Vaccine Patent \\
\hline $\begin{array}{l}\text { EP1736539, WO200679290, } \\
\text { EP3589731, KR20200014269 }\end{array}$ & $\begin{array}{l}\text { Attenuated SARS-CoV } \\
\text { vaccines }\end{array}$ \\
\hline $\begin{array}{l}\text { CN100588430C, WO200581716, } \\
\text { EP1633853, WO200793133, } \\
\text { EP1660016, US20180334480 }\end{array}$ & $\begin{array}{l}\text { Recombinant Techniques } \\
\text { based SARS-CoV } \\
\text { vaccines }\end{array}$ \\
\hline KR101132413 & $\begin{array}{l}\text { Nano-delivery system for } \\
\text { vaccine }\end{array}$ \\
\hline $\begin{array}{l}\text { WO2006/079290 (vaccinia virus carrier), } \\
\text { EP3269390 (Chimpanzee adenovirus } \\
\text { vaccine carriers), CN1616110 (SARS } \\
\text { yeast crossbreeding) }\end{array}$ & $\begin{array}{l}\text { Recombinant virus carrier } \\
\text { based }\end{array}$ \\
\hline $\begin{array}{l}\text { CN106928326 (baculovirus expresses } \\
\text { RBD (R294-F515) of SARS-CoV in } \\
\text { insect cells) }\end{array}$ & $\begin{array}{l}\text { Subunit coronavirus } \\
\text { vaccine }\end{array}$ \\
\hline CN1718243 & $\begin{array}{l}\text { Immunoadjuvant based } \\
\text { vaccine }\end{array}$ \\
\hline $\begin{array}{l}\text { EP3562504 (Plant protein signal } \\
\text { sequence as adjuvant) }\end{array}$ & Plant protein based \\
\hline
\end{tabular}

- Patents about SARS-CoV pharmaceutical compositions

Select pharmaceuticals, compounds and chemicals identified from patents, which have been claimed to be effective against SARS-CoV are listed in Table 3.

Some repurposed potential drug candidates under clinical trials for treating SARS-CoV-2 infection include lopinavir, ribavirin and Arbidol [21]. Another drug used was chloroquine in China [22]. Hydroxychloroquine has been shown to inhibit infection of cells by SARS-CoV2 in vitro, and is approved for use in malaria prophylaxis and autoimmune disease in India [23]. In April 2020 in the midst of COVID-19 pandemic India had banned export of hydroxychloroquine. However, India, as a humanitarian gesture, decided to allow supply to help countries in urgent need of the drug.

\section{India's strategic corona response}

India with a population of 1.3 billion has been actively countering the pandemic; with 543 deaths till date [24]. The reason includes sustained government efforts at all the possible levels to implement strict social distancing measures. Amongst the various COVID-19 based R\&D projects of academic institutions and firms, some of them mentioned [25] in Table 4.

\section{Conclusion}

The study of the SARS-CoV related patents reveals that specific targeting of and binding to the spike protein like structure on the nucleocapsid of the virus will aid in finding a way to contain this virus. Considering the structural similarities, an antibody that is capable of binding to the receptor-binding domain of the spike protein of the SARS-CoV2 so as to competitively inhibit the binding of the SARS-CoV-2 to host cells is the need of the hour. Of specific importance is the blocking of SARSCoV E, SARS-CoV $M$ and the SARS-CoV S-proteins. A thorough assessment of the nucleocapsid of the ever mutating SARS-CoV2 may aid scientists in finding to a lasting solution that the whole world awaits. We may also rest hope on the shortlisted drug candidates that are being re-purposed to be use in the COVID-19 pandemic. As of now, social distancing and maintaining good hygiene will immensely aid in containment measures.

Table 3. Pharmaceutical substances claimed to be potent against SARS-CoV.

\begin{tabular}{lll}
\hline Patent No. & \multicolumn{1}{c}{ Active Agent } & \multicolumn{1}{c}{ Mechanism/Action } \\
\hline $\begin{array}{l}\text { CN1699354, CN1699355 } \\
\text { KR101097189 }\end{array}$ & $\begin{array}{l}\text { 2,3,5-trisubstituted-4-thiazolidone compounds } \\
\text { Dihydroxychromone derivatives } \\
\text { Ruthenium oxalate compounds }\end{array}$ & $\begin{array}{l}\text { SARS-CoV virus 3CL protease inhibitor } \\
\text { Virus serine protease and virus polymerase inihibitor. } \\
\text { Potent inhibitory activity and cytoprotective activity to infected } \\
\text { cell. }\end{array}$ \\
& $\begin{array}{l}\text { Peptide derivatives, of which C-terminal epoxy } \\
\text { ketone structures contain - A - } \beta \text {-lactone } \\
\text { derivatives Aclacinomycin and lactacystin; } \\
\text { modified peptide aldehydes such as MG132, its } \\
\text { boric acid derivative MG232, llnl etc. }\end{array}$ & $\begin{array}{l}\text { Proteasome-Inhibitor and/or a Ubiquitin-Proteasome-Pathways } \\
\text { (UPS) Inhibitor }\end{array}$ \\
2,4-dichlorobenzyl alcohol and amylmetacresol & $\begin{array}{l}\text { Exhibits virucidal activity against SARS-associated coronavirus, } \\
\text { particularly the phenotype Urbani SARS-associated coronavirus. }\end{array}$ \\
EP1703901 & Benzopyranone derivatives & $\begin{array}{l}\text { Inhibiting the transcription or replication of 3CL proteinase } \\
\text { (3CLMpro) of SARS virus. } \\
\text { WO2007075145A1 }\end{array}$ \\
KR20200029639 & $\begin{array}{l}\text { Cyclosporin analog molecules } \\
\text { Glucosamine based composition }\end{array}$ & $\begin{array}{l}\text { Immunomodulatory agents, liposomes containing } \\
\text { immunopotentiating compositions }\end{array}$ \\
JP2020502258 & 7-thio-substituted-3-nitro-1,2,4-triazolo [5,1-c]- & Effective against single strand RNA virus infections \\
US20190055256 & $\begin{array}{l}\text { 1,2,4-triazin-4(1H)-one compounds } \\
\text { Atlantic cod (Gadus morhua) sourced trypsin } \\
\text { i.e. trypsin obtained from marine serine protease }\end{array}$ & Viricidal activity \\
WO2019135003 & &
\end{tabular}




\section{Advanced}

Table 4. Overview of S\&T accomplishments against COVID-19 in India

\begin{tabular}{|c|c|c|}
\hline Funding Agency & Institute/Firm & COVID Centric Technology \\
\hline \multirow[t]{7}{*}{$\begin{array}{l}\text { Department of Science \& } \\
\text { Technology (DST), } \\
\text { Government of India }\end{array}$} & $\begin{array}{l}\text { Genrich Membranes, Pune(a spin-off company, } \\
\text { based on proprietary technology licensed from } \\
\text { CSIR-National Chemical Laboratory) }\end{array}$ & $\begin{array}{l}\text { Membrane oxygenator equipment (MOE) to treat COVID-19 } \\
\text { patients. }\end{array}$ \\
\hline & $\begin{array}{l}\text { Sree Chitra Tirunal Institute of Medical } \\
\text { Sciences and Technology (SCTIMST), }\end{array}$ & $\begin{array}{l}\text { 1) Acrylosorb, an equipment to collect body fluids and } \\
\text { dispose safely }\end{array}$ \\
\hline & Trivandrum & $\begin{array}{l}\text { 2) Disinfected barrier-examination booth for examining } \\
\text { COVID-19 patients }\end{array}$ \\
\hline & & $\begin{array}{l}\text { 3) Emergency ventilator system based on Artificial Manual } \\
\text { Breathing Unit (AMBU) in collaboration with Wipro 3D. }\end{array}$ \\
\hline & $\begin{array}{l}\text { Department of Biosciences and Bioengineering, } \\
\text { IIT Bombay }\end{array}$ & Nasal passage gel (in developmental stage) \\
\hline & $\begin{array}{l}\text { Jawaharlal Nehru Centre for Advanced } \\
\text { Scientific Research (JNCASR), Bengaluru }\end{array}$ & $\begin{array}{l}\text { Antimicrobial coating which, when coated on different surfaces } \\
\text { such as textile, plastic and so on could kill a range of virus types } \\
\text { including COVID } 19 .\end{array}$ \\
\hline & Module Innovations & $\begin{array}{l}\text { nCoVSENSEs (TM) a rapid test device for detection of } \\
\text { COVID- } 19 \text { antibodies }\end{array}$ \\
\hline $\begin{array}{l}\text { DST and Department of } \\
\text { Biotechnology (DBT) }\end{array}$ & Weinnovate Biosolutions & $\begin{array}{l}\text { NanoAgCide technology based non-alcoholic aqueous-based } \\
\text { colloidal silver solution for disinfecting hands \& surfaces. }\end{array}$ \\
\hline \multicolumn{2}{|c|}{ Defence Research and Development Organisation (DRDO) } & Protective Biosuit for frontline medical workers \\
\hline
\end{tabular}

\section{Limitation of study}

The new coronavirus 2019-nCoV, formally termed as SARS-CoV-2 was noticed and identified only after outbreak of the novel COVID, in Wuhan province of China in November, 2019 [26]. Researchers and Scientists across the globe are immersed in researching vaccines and cure against this COVID-19 but a solution to this pandemic is yet to come. Consequently, no patent application on SARS-CoV-2 could be found.

\section{Acknowledgement}

The authors acknowledge the infrastructural support provided by National Research Development Corporation in conducting the study.

\section{Keywords}

Corona Virus, Cure, COVID-19, SARS-CoV, Patent.

\section{References}

1. Kan, B.; Wang, M.; Jing, H.; Xu, H.; Jiang, X.; Yan, M. et al., Journal of virology, 2005, 79, 11892.

2. Lu, R.; Zhao, X.; Li, J.; Niu, P.; Yang, B.; Wu, H. et al., Lancet, 2020, 395, 565.

3. Coronaviridae Study Group of the International Committee on Taxonomy of Viruses, Nature Microbiology 2020, 5, 536.

4. Remuzzi, A.; Remuzzi, G., Lancet, 2020, 395, 1225.

5. "Countries where COVID-19 has spread", viewed 20th April, 2020, $<$ https://www.worldometers.info/coronavirus/countries-wherecoronavirus-has-spread/>

6. Mishra, A.; Patra, S.; Shukla, S.; Pandey, P.; Adv. Mater. Lett., 2020, 11, 20041494

7. Cui, J.; Li, F.; Shi, Z.L.; Nat Rev Microbiol., 2019, 17, 181.

8. Tang, B.; Bragazzi, N. L.; Li, Q.; Tang, S.; Xiao, Y.; Wu, J., Infectious disease modelling, 2020, 5, 248.

9. Liu, C.; Zhou, Q.; Li, Y.; Garner, L. V.; Watkins, S. P.; Carter, L. J. et al., ACS Cent. Sci., 2020, 6, 3, 315 .

10. For the purpose of this study, patent refers to both patent applications and granted patents.

11. 'WO2019135003' viewed 18th April, 2020, $<$ https://patentscope. wipo.int/search/en/detail.jsf?docId=WO20191 35003>
12. He, F.; Deng, Y.; Li, W ; J. Med. Virol., 2020

13. Chen, Y.; Liu, Q.; Guo, D.; J. Med. Virol., 2020, 92, 418.

14. Li, X.; Zai, J.; Zhao, Q.; Nie, Q.; Li, Y.; Foley, B. T.; Chaillon, A.; J. Med. Virol., 2020.

15. Sun, J.; He, W. T.; Wang, L.; Lai, A.; Ji, X.; Zhai, X. et al., Trends in Molecular Medicine, 2020.

16. "Covid Patent Landscape" viewed 14th April, 2020 <https://www.patentwire.co.in/ebooks/covid-patent-landscape/ >

17. Some prominent patent applicants for diagnostic methods include Institute of Pathogen Biology Chinese Academy Of Medical Sciences, Chinese University Of Hong Kong, Century Biotech, Versitech, University Health Network, Huanqiu Zhongjia Biotechnology Co., Ltd., University of North Carolina, Beijing Genovax Biotech Corporation, University of Texas System, Sun Yat-Sen University, Academia Sinica, Chinese Academy of Medical Sciences, Yung Shin Pharmaceutical Industrial Co., National Institutes of Health (USA), Sanofi-Aventis, Academy of Military Medical Sciences.

18. Fudan University from China, John Hopkins University, University of Massachusetts, Loyola University of Chicago, University of Maryland, Thomas Jefferson University, Yale University, Harvard College all from USA, Seoul National University from Korea, Ramot At Tel Aviv University from Israel are amongst the universities engaged in research about SARS-CoV vaccines.

19. Vical, United States, MSD Italia, Italy, Glaxosmithkline Biologicals, Belgium, ID Biomedical Corporation, Canada, Protein Potential, United States, Modernatx, United States are amongst the firms engaged in research about SARS-CoV vaccines.

20. R\&D institutions owning inventions about SARS-CoV vaccines include Spanish National Research Council of Madrid, Aaron Diamond AIDS Research Center of New York, Chinese Center for Disease Control and Prevention of Beijing, HKU Pasteur Research Center Dexter, Hong Kong, Institute of Zoology, Chinese Academy of Sciences of Beijing, New York Blood Center of New York, National Ophthalmic Disease Genotyping and Phenotyping Network (eyeGENE®), USA, Agenzia nazionale per le nuove tecnologie, l'energia e lo sviluppo economico sostenibile, Italy, Chinese Center for Disease Control and Prevention Center for Aids/STD Control and Prevention, Beijing, China.

21. The Efficacy of Lopinavir Plus Ritonavir and Arbidol Against Novel Coronavirus Infection (ELACOI). https://clinicaltrials.gov/ct2/show/NCT04252885

22. Gao, J.; Tian, Z.; Yang, X.; BioScience Trends., 2020, 14, 72. 


\section{Advanced}

\section{Materials Letters}

www. vbripress.com/aml

23. Singh, A. K.; Singh, A.; Shaikh, A.; Singh, R.; Misra, A.; Diabetes Metab. Syndr., 2020, 14, 241.

24. "COVID-19 INDIA" viewed 20th April, 2020, < https://www.mohfw.gov.in/>

25. "Information sourced from Vigyan Prasar Report titled 'Science \& Technology Efforts in India on COVID-19" viewed 18th April, 2020, <http://www.nrdcindia.com/assets/vendor/filemanager/ userfiles/Latest_News/Covid_Newsletter.pdf> and $<$ http://www.nrdcindia.com/assets/vendor/filemanager/userfiles/Lat est_News/COVID19_APRIL_17_Final_Edition-2-min.pdf>

26. Lai, C. C.; Shih, T. P.; Ko, W. C.; Tang, H. J.; Hsueh, P. R.; Int. J. Antimicrob. Agents, 2020, 55, 105924. 